\title{
Reactions of 3-(p-substituted-phenyl)-5-chloromethyl-1,2,4- oxadiazoles with KCN leading to acetonitriles and alkanes via a non-reductive decyanation pathway
}

\author{
Akın Sağırlı* and Yaşar Dürüst
}

\author{
Full Research Paper \\ Address: \\ Department of Chemistry, Faculty of Arts \& Sciences, Bolu Abant \\ Izzet Baysal University, Bolu, TR14030, Turkey \\ Email: \\ Akın Sağırıı* - sagirli_a@ibu.edu.tr \\ * Corresponding author \\ Keywords: \\ decyanation; $\mathrm{KCN} ; 1$,2,4-oxadiazole
}

\author{
Beilstein J. Org. Chem. 2018, 14, 3011-3017. \\ doi:10.3762/bjoc. 14.280 \\ Received: 06 October 2018 \\ Accepted: 28 November 2018 \\ Published: 10 December 2018 \\ Associate Editor: J. A. Murphy \\ (C) 2018 Sağırlı and Dürüst; licensee Beilstein-Institut. \\ License and terms: see end of document.
}

\begin{abstract}
The present work describes an unfamiliar reaction of 5-(chloromethyl)-3-substituted-phenyl-1,2,4-oxadiazoles with KCN affording trisubstituted 1,2,4-oxadiazol-5-ylacetonitriles and their parent alkanes, namely, 1,2,3-trisubstituted-1,2,4-oxadiazol-5-ylpropanes. To the best of our knowledge, the current synthetic route leading to decyanated products will be the first in terms of a decyanation process which allows the transformation of trisubstituted acetonitriles into alkanes by the incorporation of KCN with the association of in situ-formed HCN and most likely through the extrusion of cyanogen which could not be detected or isolated. In addition, the plausible mechanisms were proposed for both transformations. The structures of the title compounds were identified by means of IR, ${ }^{1} \mathrm{H}$ NMR, ${ }^{13} \mathrm{C}$ NMR, 2D NMR spectra, TOF-MS and X-ray measurements.
\end{abstract}

\section{Introduction}

Heterocyclic scaffolds bearing 1,2,4-oxadiazole rings have been the subject of an increasing and remarkable attention due to their various bioactivities, such as anticancer [1], antimicrobial [2], antifungal [3], anti-inflammatory [4], tyrosine kinase inhibition [5] and histamine $\mathrm{H} 3$ antagonism properties [6]. In addition, these five-membered heterocycles were widely used as components of organic light emitting diodes (OLEDs), polymers, liquid crystals, and solar cells [7-10]. Taking into account the above considerations, new synthetic protocols to develop 1,2,4-oxadiazole-based heterocycles have gained an increasing attention over the recent decades [11-13].
On the other hand, arylacetonitriles are known as valuable intermediates that are generally obtained by the reaction of benzyl halides with appropriate cyanating agents such as KCN [14], TMSCN [15], $\mathrm{K}_{4}\left(\mathrm{Fe}(\mathrm{CN})_{6}\right.$ [16]. Deprotonation of the $\alpha$-carbon (adjacent to nitrile) by strong bases, especially lithiated ones, resulted in an anionic species that easily undergoes a substitution reaction with various alkyl halides to afford mono-, di- or trialkylated acetonitriles [17]. Most recently, Strzalko and co-workers disclose mono and dialkylation of the benzylic carbon of phenylacetonitrile with a poor selectivity by benzyl and methyl halides in the presence of LiHMDS, LDA or $n$-BuLi 
(Figure 1) [18]. However, such alkylation methods need harsh reaction conditions, most particularly lithiated bases and inert atmosphere.

$$
\begin{aligned}
& \overbrace{\mathrm{CN}} \frac{\mathrm{R}^{1}-\mathrm{X}}{\mathrm{R}: \text { phenyl }} \\
& \mathrm{R}^{1}: \mathrm{Me}, \mathrm{CH}_{2} \mathrm{Ph}
\end{aligned}
$$

Figure 1: Synthesis of mono- or dialkylated acetonitriles.

In order to get a deeper understanding of the limitation step of alkylation processes and to extend their scope in the synthesis of mono-, di- or trialkylated structures, cyanation attempts of 5-(chloromethyl)-3-phenyl-1,2,4-oxadiazoles 1 with excess $\mathrm{KCN}$ at room temperature in $\mathrm{CH}_{3} \mathrm{CN}$ have been investigated leading to trisubstituted acetonitrile $\mathbf{3}$ instead of anticipated product 2 . This result is in accord with a previous report where only one example (3a) has been exploited by providing very limited structural data [19]. Interestingly, increasing the reaction temperature to $100{ }^{\circ} \mathrm{C}$ yielded 1,2,4-oxadiazole-substituted propanes $\mathbf{4}$ as the major products which can only be interpreted via a decyanation pathway of cyanated oxadiazoles 3 (Figure 2).

Up to date, various methods have been reported for the conversion of organic nitriles into the parent alkanes; such as oxidative decyanation [20], dehydrocyanation [21] and more commonly, reductive decyanation [22]. Among them, the reductive decyanation is a widely used method employing metal hydrides [23], electrolysis [24], transition metal complexes [25], and alkali metals in a variety of solvents [26]. Generally, they require mostly an inert atmosphere as well as harsh reaction conditions. These facts constitute challenges to the development of mild reaction conditions in the reduction of nitrilated compounds.

In the light of the above considerations, we report here an unfamiliar example of non-reductive decyanation through the reaction of 5-(chloromethyl)-3-(substituted-phenyl)-1,2,4-oxadiazoles 1 with 2 equiv of $\mathrm{KCN}$ at $100{ }^{\circ} \mathrm{C}$ in a single step transformation.

\section{Results and Discussion}

In the first part of this work, 5-(chloromethyl)-3-(substitutedphenyl)-1,2,4-oxadiazoles 1 were obtained via a previously published literature procedure by reacting $p$-substituted benzamidoximes with chloroacetyl chloride in refluxing benzene [27]. After having been obtained the starting oxadiazoles, our goal was to replace the chlorine atom with a $\mathrm{CN}^{-}$anion by a simple $\mathrm{S}_{\mathrm{N}} 2$ reaction. For this purpose, 5-chloromethyl-1,2,4oxadiazole 1a was reacted with 10 equiv of $\mathrm{KCN}$ in $\mathrm{CH}_{3} \mathrm{CN}$ at reflux, after completion of the reaction on the basis of TLC, surprisingly we obtained a mixture of products 4 (major) and $\mathbf{3}$ (minor, Table 1, entry 1). This unexpected product distribution of the reaction prompted us to investigate the reaction of 5-(chloromethyl)-3-( $p$-substituted-phenyl)-1,2,4-oxadiazoles 1 with $\mathrm{KCN}$.

Our initial effort was to investigate the limitation of the reaction. For this, the effect of temperature on this reaction was examined in $\mathrm{CH}_{3} \mathrm{CN}$ with various equivalents of $\mathrm{KCN}$ and

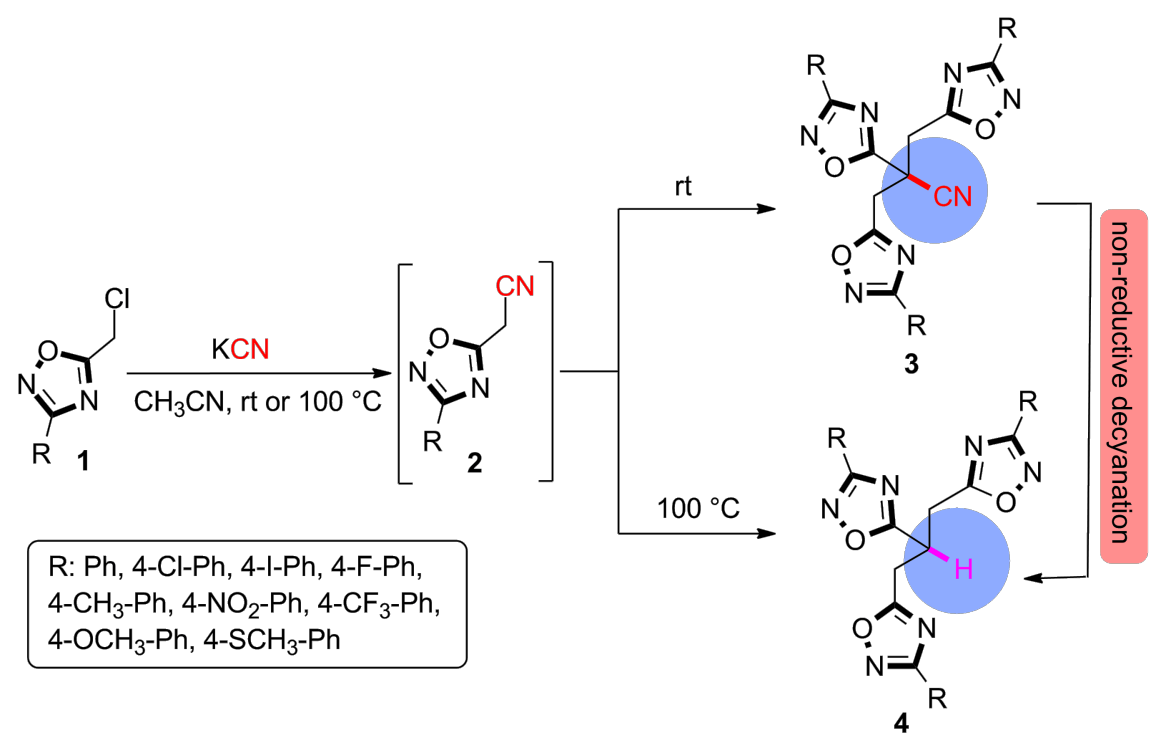

Figure 2: Cyanation through 5-chloromethyl-3-(p-substituted-phenyl)-1,2,4-oxadiazole. 
Table 1: Optimisation of reaction conditions.

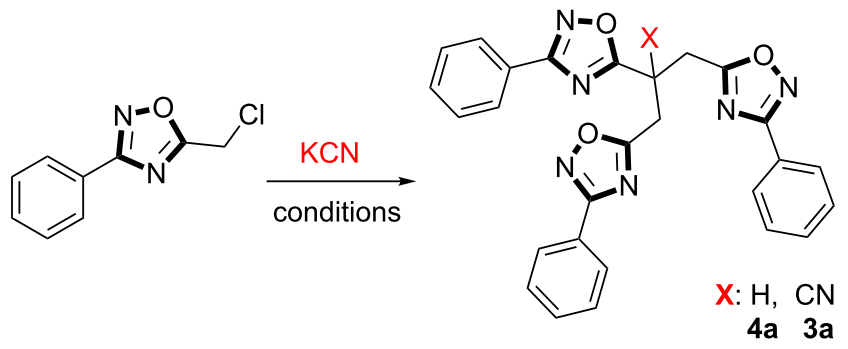

\begin{tabular}{|c|c|c|c|c|}
\hline \multirow[b]{2}{*}{ Entry } & \multirow[b]{2}{*}{$\mathrm{KCN}$ (equiv) $^{\mathrm{a}}$} & \multirow[b]{2}{*}{ Conditions } & \multicolumn{2}{|c|}{ Yield $(\%)^{b}$} \\
\hline & & & $4 a$ & $3 a$ \\
\hline 1 & 10 & $\mathrm{CH}_{3} \mathrm{CN}, 80^{\circ} \mathrm{C}, 3 \mathrm{~h}$ & 55 & 32 \\
\hline 2 & 10 & $\mathrm{CH}_{3} \mathrm{CN}, 80^{\circ} \mathrm{C}, 12 \mathrm{~h}$ & 70 & 15 \\
\hline 3 & 10 & $\mathrm{CH}_{3} \mathrm{CN}, 100^{\circ} \mathrm{C}, 12 \mathrm{~h}$ & 75 & trace \\
\hline 4 & 10 & $\mathrm{CH}_{3} \mathrm{CN}, 110^{\circ} \mathrm{C}, 12 \mathrm{~h}$ & 75 & trace \\
\hline $5^{c}$ & 2 & $\mathrm{CH}_{3} \mathrm{CN}, 100^{\circ} \mathrm{C}, 24 \mathrm{~h}$ & 75 & trace \\
\hline 6 & 10 & $\mathrm{CH}_{3} \mathrm{CN}, \mathrm{rt}, 12 \mathrm{~h}$ & trace & 85 \\
\hline 7 & 6 & $\mathrm{CH}_{3} \mathrm{CN}, \mathrm{rt}, 20 \mathrm{~h}$ & trace & 85 \\
\hline $8^{d}$ & 4 & $\mathrm{CH}_{3} \mathrm{CN}, \mathrm{rt}, 24 \mathrm{~h}$ & trace & 85 \\
\hline 9 & 2 & $\mathrm{CH}_{3} \mathrm{CN}, \mathrm{rt}, 24 \mathrm{~h}$ & - & 52 \\
\hline
\end{tabular}

aEquivalent of $\mathrm{KCN}$ respect to $1 \mathrm{a} .{ }^{\mathrm{b}} \mathrm{All}$ yields were calculated after purification by flash chromatography. ${ }^{\mathrm{C}}$ The most effective method for the formation of $4 a$. dThe most effective method for the formation of $3 a$.

varying reaction times (Table 1, entries 2-6). Treatment of 1a with 10 equiv of $\mathrm{KCN}$ at $100{ }^{\circ} \mathrm{C}$ gave mainly product $4 \mathbf{a}$ with a yield of $75 \%$, as well as product 3a in trace amounts even when heating at $110{ }^{\circ} \mathrm{C}$. Due to the toxic nature of $\mathrm{KCN}$, the minimum amount of $\mathrm{KCN}$ was determined for optimal formation of $4 \mathbf{a}$. When 2 equiv of $\mathrm{KCN}$ was used instead of 10 equiv at $100{ }^{\circ} \mathrm{C}$ in $\mathrm{CH}_{3} \mathrm{CN}$, the reaction proceeded to give compound 4a with a yield of $75 \%$ again, but $24 \mathrm{~h}$ for completion of the reaction were needed.

In further trials, we aimed to decrease the reaction temperature from $100{ }^{\circ} \mathrm{C}$ to room temperature in $\mathrm{CH}_{3} \mathrm{CN}$ using 10 equiv of $\mathrm{KCN}$. In this case, the reaction ended with the formation of compound 3a as a major product (85\%) and decyanated product 4a was obtained in trace amounts. To optimize the reaction conditions for compound 3a, different equivalents of KCN have been tried. We were pleased to find that the use of 4 equiv $\mathrm{KCN}$ in $\mathrm{CH}_{3} \mathrm{CN}$ gave the desired product $\mathbf{3 a}$ in high yield with a trace amount of decyanated product $\mathbf{4 a}$.

After having the optimized reaction conditions, 5-(chloromethyl)-3-( $p$-substituted-phenyl)-1,2,4-oxadiazoles 1 were reacted sequentially with 2 equiv of $\mathrm{KCN}$ in $\mathrm{CH}_{3} \mathrm{CN}$ at $100{ }^{\circ} \mathrm{C}$ and 4 equiv of $\mathrm{KCN}$ in $\mathrm{CH}_{3} \mathrm{CN}$ at room temperature giving the title compounds $\mathbf{3}$ and $\mathbf{4}$ as major products in high yields (75-85\%, Table 2). Interestingly, incorporation of electron-poor substituents in compounds $\mathbf{1 f}$ and $\mathbf{1 g}$ with 2 equiv of $\mathrm{KCN}$ at $100{ }^{\circ} \mathrm{C}$ (method A) afforded only the products $\mathbf{4 f}$ and $\mathbf{4 g}$, respectively, in a shorter reaction time (Table 2, entries 6 and 7).

However, due to the replacement of the nitrile group with hydrogen after decyanation in product $\mathbf{4}$, the methylenic protons and the methinic proton resonates at around $4-5 \mathrm{ppm}$ as doublets and $5 \mathrm{ppm}$ as pentet, respectively (Figure 3 ). The aliphatic protons of title compounds $\mathbf{3}$ and $\mathbf{4}$ were also assigned on the basis of HSQC and HMBC NMR experiments. The expanded HSQC spectrum of 3a showed the C2 carbon at 35 ppm which corresponds to the methylenic hydrogens $\mathrm{H} 2$. In addition, the HSQC spectrum of 4 a showed that the H1 proton located between the methylene coupled with the $\mathrm{C} 1$ carbon and that the methylene protons $\mathrm{H} 2$ were incorporated in the $\mathrm{C} 2$ carbon signal.

Fortunately, the exact structures of compounds $3 \mathbf{a}$ and $4 \mathbf{e}$ were also confirmed by X-ray structures (Figure 4). The CIF data of 3a and 4e have been deposited at Cambridge Crystallographic Data Centre with the deposition numbers 1844118 and 1832133.

We propose a plausible mechanism for the transformation of chloromethyloxadiazoles 1 into the title products 3 and $\mathbf{4}$. Accordingly, the reaction of $\mathbf{1}$ with a $\mathrm{CN}^{-}$anion gives 
Table 2: Formation of 3 and their parent alkanes 4.<smiles>[R]c1ccc(-c2noc(CCl)n2)cc1</smiles><smiles>[R]c1ccc(-c2noc(CC([X])(Cc3nc(-c4ccc([R])cc4)no3)c3nc(-c4ccc([R])cc4)no3)n2)cc1</smiles>

\begin{tabular}{|c|c|c|c|c|c|c|c|}
\hline \multirow[b]{3}{*}{ Entry } & \multirow[b]{3}{*}{ Substrate } & \multirow[b]{3}{*}{4} & \multirow[b]{3}{*}{3} & \multicolumn{4}{|c|}{ Yield (\%) } \\
\hline & & & & \multicolumn{2}{|c|}{ Method $A^{a}$} & \multicolumn{2}{|c|}{ Method $\mathrm{B}^{\mathrm{b}}$} \\
\hline & & & & 3 & 4 & 3 & 4 \\
\hline 1 & 1a: $R=H$ & 4a: $R=H ; X=H$ & 3a: $\mathrm{R}=\mathrm{H} ; \mathrm{X}=\mathrm{CN}$ & trace & 75 & 85 & 5 \\
\hline 2 & 1b: $\mathrm{R}=\mathrm{Cl}$ & 4b: $\mathrm{R}=\mathrm{Cl} ; \mathrm{X}=\mathrm{H}$ & 3b: $\mathrm{R}=\mathrm{Cl} ; \mathrm{X}=\mathrm{CN}$ & 7 & 70 & 78 & trace \\
\hline 3 & 1c: $R=1$ & 4c: $\mathrm{R}=\mathrm{I} ; \mathrm{X}=\mathrm{H}$ & 3c: $\mathrm{R}=\mathrm{I} ; \mathrm{X}=\mathrm{CN}$ & 5 & 68 & 72 & trace \\
\hline 4 & 1d: $R=F$ & $\mathbf{4 d}: \mathrm{R}=\mathrm{F} ; \mathrm{X}=\mathrm{H}$ & 3d: $\mathrm{R}=\mathrm{F} ; \mathrm{X}=\mathrm{CN}$ & 7 & 65 & 70 & trace \\
\hline 5 & 1e: $\mathrm{R}=\mathrm{CH}_{3}$ & 4e: $\mathrm{R}=\mathrm{CH}_{3} ; \mathrm{X}=\mathrm{H}$ & 3e: $\mathrm{R}=\mathrm{CH}_{3} ; \mathrm{X}=\mathrm{CN}$ & trace & 72 & 82 & 5 \\
\hline 6 & 1f: $\mathrm{R}=\mathrm{NO}_{2}$ & 4f: $\mathrm{R}=\mathrm{NO}_{2} ; \mathrm{X}=\mathrm{H}$ & 3f: $\mathrm{R}=\mathrm{NO}_{2} ; \mathrm{X}=\mathrm{CN}$ & - & $82^{c}$ & 78 & 15 \\
\hline 7 & 1g: $\mathrm{R}=\mathrm{CF}_{3}$ & $\mathbf{4 g}: \mathrm{R}=\mathrm{CF}_{3} ; \mathrm{X}=\mathrm{H}$ & 3g: $\mathrm{R}=\mathrm{CF}_{3} ; \mathrm{X}=\mathrm{CN}$ & - & $78^{d}$ & 75 & 12 \\
\hline 8 & 1h: $\mathrm{R}=\mathrm{OCH}_{3}$ & 4h: $\mathrm{R}=\mathrm{OCH}_{3} ; \mathrm{X}=\mathrm{H}$ & 3h: $\mathrm{R}=\mathrm{OCH}_{3} ; \mathrm{X}=\mathrm{CN}$ & 5 & 70 & 78 & trace \\
\hline 9 & 1j: $\mathrm{R}=\mathrm{SCH}_{3}$ & $4 \mathrm{j}: \mathrm{R}=\mathrm{SCH}_{3} ; \mathrm{X}=\mathrm{H}$ & 3j: $\mathrm{R}=\mathrm{SCH}_{3} ; \mathrm{X}=\mathrm{CN}$ & 7 & 72 & 76 & trace \\
\hline
\end{tabular}

${ }^{a} \mathrm{CH}_{3} \mathrm{CN}, 2$ equiv $\mathrm{KCN}, 100{ }^{\circ} \mathrm{C}, 12 \mathrm{~h}{ }^{\mathrm{b}} \mathrm{CH}_{3} \mathrm{CN}, 4$ equiv $\mathrm{KCN}, \mathrm{rt}, 24 \mathrm{~h}{ }^{\mathrm{c}} \mathrm{CH}_{3} \mathrm{CN}, 2$ equiv $\mathrm{KCN}, 100{ }^{\circ} \mathrm{C}, 6 \mathrm{~h}{ }^{\mathrm{d}} \mathrm{CH}_{3} \mathrm{CN}, 2$ equiv $\mathrm{KCN}, 100{ }^{\circ} \mathrm{C}, 8 \mathrm{~h}$.
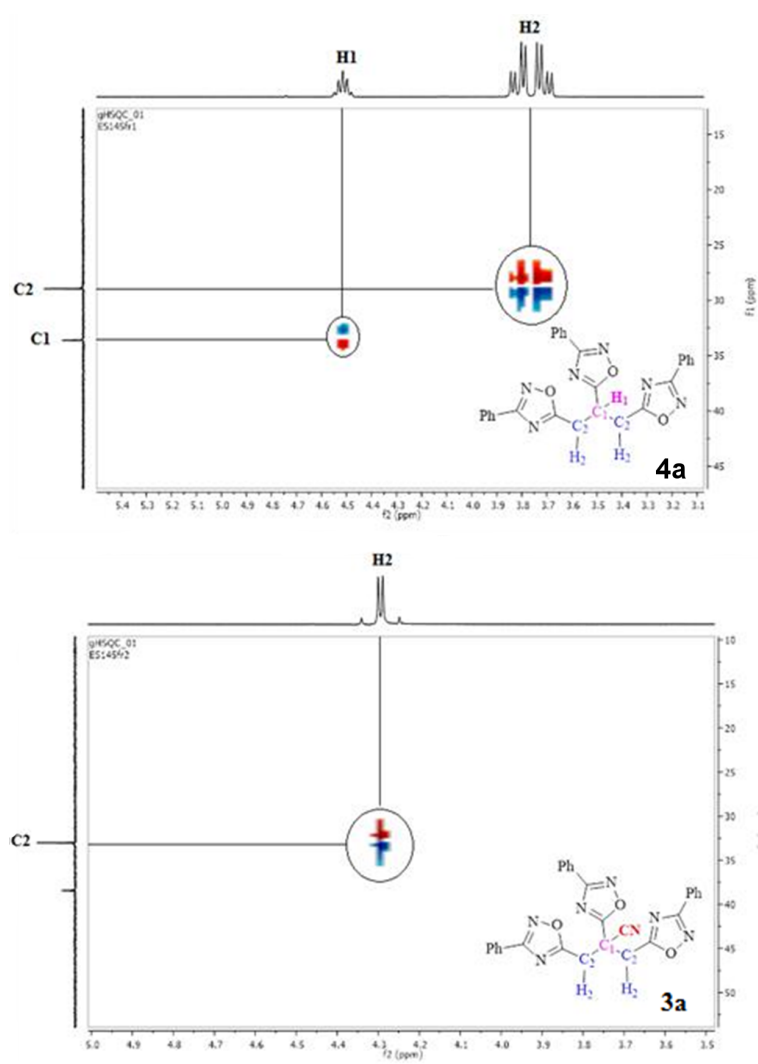

Figure 3: Expanded HSQC spectrum of $4 \mathbf{a}$ and $3 a$.
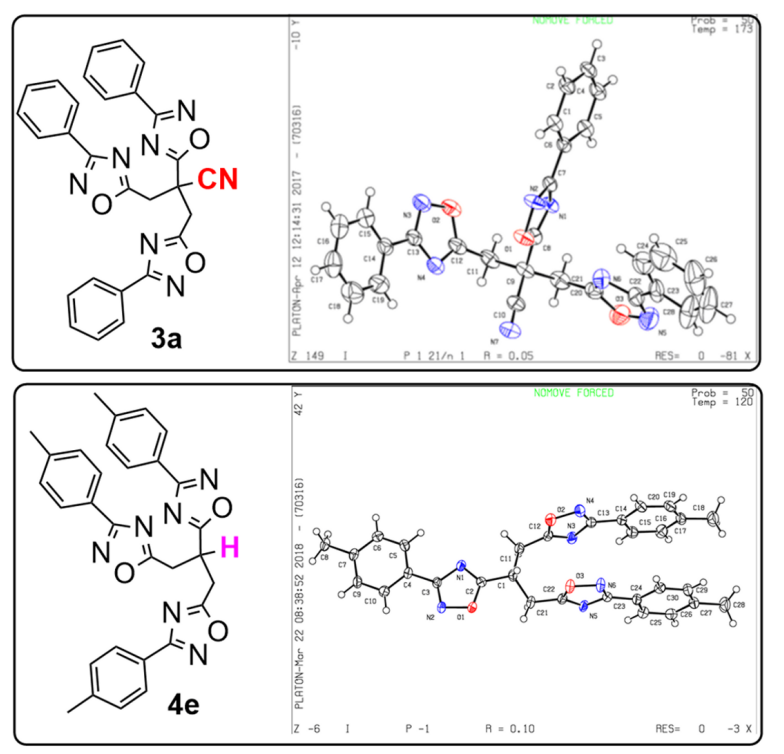

Figure 4: X-ray ORTEP plots of $3 \mathbf{a}$ and $4 \mathrm{e}$.

cyanomethyloxadiazole by simple $\mathrm{S}_{\mathrm{N}} 2$ reaction. Then, the acidic hydrogen adjacent to the nitrile group in the intermediate product is sequentially abstracted by a $\mathrm{CN}^{-}$anion with the extrusion of an HCN molecule and a carbanion alpha to the nitrile group bearing a 1,2,4-oxadiazole ring is formed. The resulted carbanion undergoes a substitution reaction with 
another molecule of $\mathbf{1}$, affording di-1,2,4-oxadiazole-substituted acetonitrile, which then undergoes a second substitution reaction with another molecule of $\mathbf{1}$, in the same manner, finally affording title compound $\mathbf{3}$ (Scheme 1).

Considering the formation of product $\mathbf{4}$, as we believe, the temperature plays a significant role upon formation of it and in situformed $\mathrm{HCN}$ facilitates the decyanation (nitrile-alkane conver- sion) possibly since it is the only proton source in the reaction medium. This unfamiliar decyanation reaction presumably proceeds through product 3. First, in the presence of $\mathrm{CN}^{-}$ anions, cyanoimine salt intermediate $\mathbf{A}$ forms by addition to a nitrile. Then, a possible cyanogen release would occur to form intermediate $\mathbf{B}$. The imine-enamine tautomerization of $\mathbf{B}$ by the effect of in situ-generated HCN results in the desired decyanated product 4 (Scheme 2).

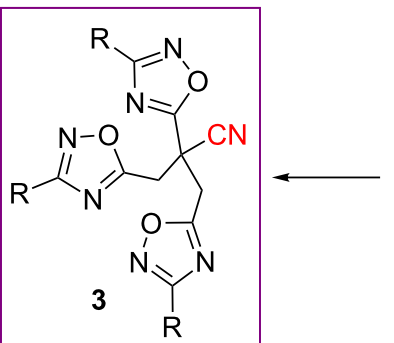

R: 4-substituted phenyl

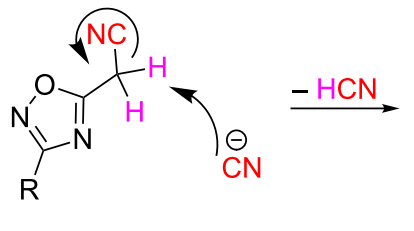

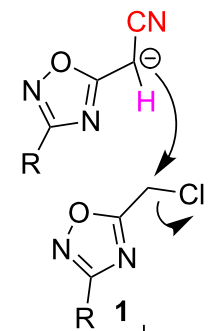<smiles>[R]c1noc(CC(OCC(C)(Cl)c2nc([R])no2)c2nonc2[R])n1</smiles><smiles>[R]c1noc(C=C(C#N)c2nc([R])no2)n1</smiles>

$R$

Scheme 1: Plausible mechanism for the formation of 3.<smiles>[R]c1noc(CC(C#N)(Cc2nc([R])no2)c2nc([R])no2)n1</smiles>

3<smiles>[R]c1noc(CCl)n1</smiles>

1

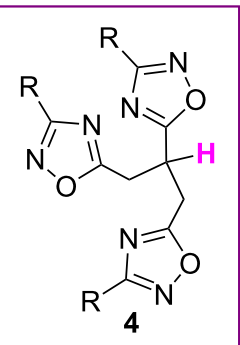

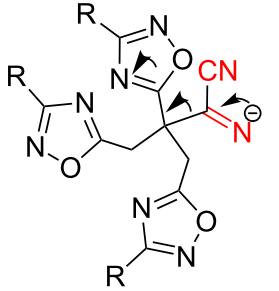

$-(\mathrm{N} \equiv \quad \equiv \mathrm{N})$

cyanogen

$\stackrel{\text { imine-enamine }}{\text { tautomerization }}$

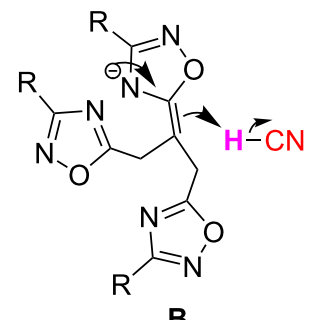




\section{Conclusion}

In summary, we reported a convenient one-pot protocol for the synthesis of $\mathbf{3}$ and its transformation into $\mathbf{4}$ via a decyanation pathway by the reaction of 5-(chloromethyl)-3-( $p$-substitutedphenyl)-1,2,4-oxadiazoles 1 with KCN at different temperatures. This decyanation method is the first example for the conversion of a nitrile group into an alkane by using $\mathrm{KCN}-\mathrm{HCN}$ associates through a possible release of cyanogen which is not detected or isolated. This synthetic protocol seems to be applicable for further decyanation processes containing a 1,2,4-oxadiazole moiety.

\section{Supporting Information}

\section{Supporting Information File 1}

Experimental details, characterization data and copies of NMR spectra.

[https://www.beilstein-journals.org/bjoc/content/ supplementary/1860-5397-14-280-S1.pdf]

\section{Acknowledgements}

TÜBİTAK (Turkish Scientific and Technological Research Council, grant no. 115Z581) is gratefully acknowledged for financial support

\section{References}

1. Moniot, S.; Forgione, M.; Lucidi, A.; Hailu, G. S.; Nebbioso, A.; Carafa, V.; Baratta, F.; Altucci, L.; Giacché, N.; Passeri, D.; Pellicciari, R.; Mai, A.; Steegborn, C.; Rotili, D. J. Med. Chem. 2017, 60, 2344-2360. doi:10.1021/acs.jmedchem.6b01609

2. O'Daniel, P. I.; Peng, Z.; Pi, H.; Testero, S. A.; Ding, D.; Spink, E.; Leemans, E.; Boudreau, M. A.; Yamaguchi, T.; Schroeder, V. A.; Wolter, W. R.; Llarrull, L. I.; Song, W.; Lastochkin, E.; Kumarasiri, M.; Antunes, N. T.; Espahbodi, M.; Lichtenwalter, K.; Suckow, M. A.; Vakulenko, S.; Mobashery, S.; Chang, M. J. Am. Chem. Soc. 2014, 136, 3664-3672. doi:10.1021/ja500053x

3. Karad, S. C.; Purohit, V. B.; Thummar, R. P.; Vaghasiya, B. K.; Kamani, R. D.; Thakor, P.; Thakkar, V. R.; Thakkar, S. S.; Ray, A.; Raval, D. K. Eur. J. Med. Chem. 2017, 126, 894-909. doi:10.1016/j.ejmech.2016.12.016

4. Heimann, D.; Börgel, F.; de Vries, H.; Bachmann, K.; Rose, V. E.; Frehland, B.; Schepmann, D.; Heitman, L. H.; Wünsch, B. Eur. J. Med. Chem. 2018, 143, 1436-1447. doi:10.1016/j.ejmech.2017.10.049

5. Leite, A. C. L.; Vieira, R. F.; de Faria, A. R.; Wanderley, A. G.; Afiatpour, P.; Ximenes, E. C. P. A.; Srivastava, R. M.; de Oliveira, C. F.; Medeiros, M. V.; Antunes, E.; Brondani, D. J. Farmaco 2000, 55, 719-724. doi:10.1016/s0014-827x(00)00099-9

6. Yang, X.; Liu, G.; Li, H.; Zhang, Y.; Song, D.; Li, C.; Wang, R.; Liu, B.; Liang, W.; Jing, Y.; Zhao, G. J. Med. Chem. 2010, 53, 1015-1022. doi:10.1021/jm9011565

7. Wei, H.; He, C.; Zhang, J.; Shreeve, J. N. M. Angew. Chem., Int. Ed. 2015, 54, 9367-9371. doi:10.1002/anie.201503532
8. Li, Q.; Cui, L.-S.; Zhong, C.; Jiang, Z.-Q.; Liao, L.-S. Org. Lett. 2014, 16, 1622-1625. doi:10.1021/ol5002494

9. Guo, J.; Hua, R.; Sui, Y.; Cao, J. Tetrahedron Lett. 2014, 55, 1557-1560. doi:10.1016/j.tetlet.2014.01.066

10. Li, Q.; Cui, L.-S.; Zhong, C.; Yuan, X.-D.; Dong, S.-C.; Jiang, Z.-Q.; Liao, L.-S. Dyes Pigm. 2014, 101, 142-149. doi:10.1016/j.dyepig.2013.09.029

11. Wang, W.; Xu, H.; Xu, Y.; Ding, T.; Zhang, W.; Ren, Y.; Chang, H. Org. Biomol. Chem. 2016, 14, 9814-9822. doi:10.1039/c6ob01794k

12. Kuram, M. R.; Kim, W. G.; Myung, K.; Hong, S. Y. Eur. J. Org. Chem. 2016, 438-442. doi:10.1002/ejoc.201501502

13. Grant, D.; Dahl, R.; Cosford, N. D. P. J. Org. Chem. 2008, 73, 7219-7223. doi:10.1021/jo801152c

14. Chidambaram, M.; Sonavane, S. U.; de la Zerda, J.; Sasson, Y. Tetrahedron 2007, 63, 7696-7701. doi:10.1016/j.tet.2007.05.017

15. Ren, Y.; Dong, C.; Zhao, S.; Sun, Y.; Wang, J.; Ma, J.; Hou, C. Tetrahedron Lett. 2012, 53, 2825-2827. doi:10.1016/j.tetlet.2012.03.109

16. Brunel, J.-M.; Holmes, I. P. Angew. Chem., Int. Ed. 2004, 43, 2752-2778. doi:10.1002/anie.200300604

17. Tsao, J.-P.; Tsai, T.-Y.; Chen, I.-C.; Liu, H.-J.; Zhu, J.-L.; Tsao, S.-W. Synthesis 2010, 4242-4250. doi:10.1055/s-0030-1258301

18. Strzalko, T.; Wartski, L.; Corset, J.; Castellà-Ventura, M.; Froment, F. J. Org. Chem. 2012, 77, 6431-6442. doi:10.1021/jo300758g

19. Jaunin, R. Helv. Chim. Acta 1966, 49, 412-419. doi:10.1002/hlca.660490146

20. Parker, K. A.; Kallmerten, J. L. Tetrahedron Lett. 1979, 20, 1197-1200. doi:10.1016/s0040-4039(01)86101-3

21. Ahlbrecht, H.; Raab, W.; Vonderheid, C. Synthesis 1979, 127-129. doi:10.1055/s-1979-28587

22. Too, P. C.; Chan, G. H.; Tnay, Y. L.; Hirao, H.; Chiba, S. Angew. Chem., Int. Ed. 2016, 55, 3719-3723. doi:10.1002/anie.201600305

23. Marshall, J. A.; Bierenbaum, R. J. Org. Chem. 1977, 42, 3309-3311. doi:10.1021/jo00440a029

24. Franck-Neumann, M.; Miesch, M.; Lacroix, E.; Mertz, B.; Ken, J.-M. Tetrahedron 1992, 48, 1911-1926. doi:10.1016/s0040-4020(01)88514-8

25. Chang, K.-J.; Rayabarapu, D. K.; Cheng, C.-H. J. Org. Chem. 2004, 69, 4781-4787. doi:10.1021/jo049506g

26. Yamada, S.-i.; Tomioka, K.; Koga, K. Tetrahedron Lett. 1976, 17, 61-64. doi:10.1016/s0040-4039(00)71323-2

27. Ağırbaş, H.; Sümengen, D.; Dürüst, Y.; Dürüst, N. Synth. Commun. 1992, 22, 209-217. doi:10.1080/00397919208021295 


\section{License and Terms}

This is an Open Access article under the terms of the Creative Commons Attribution License

(http://creativecommons.org/licenses/by/4.0). Please note that the reuse, redistribution and reproduction in particular requires that the authors and source are credited.

The license is subject to the Beilstein Journal of Organic Chemistry terms and conditions:

(https://www.beilstein-journals.org/bjoc)

The definitive version of this article is the electronic one which can be found at:

doi:10.3762/bjoc. 14.280 